Article

\title{
Novel Angiotensin-Converting Enzyme Inhibitory Peptides Identified from Walnut Glutelin-1 Hydrolysates: Molecular Interaction, Stability, and Antihypertensive Effects
}

\author{
Jing Wang ${ }^{1,2,3}{ }^{\oplus}$, Guoliang Wang ${ }^{1}$, Yufeng Zhang ${ }^{1,4}{ }^{\oplus}$, Runguang Zhang ${ }^{1}$ and Youlin Zhang ${ }^{1, *}$ \\ 1 College of Food Engineering and Nutritional Science, Shaanxi Normal University, Xi'an 710119, China; \\ wj_sxxqsfxy@163.com (J.W.); guoliangw@snnu.edu.cn (G.W.); zhangyufeng062@163.com (Y.Z.); \\ sunshine@snnu.edu.cn (R.Z.) \\ 2 College of Life Sciences and Food Engineering, Shaanxi Xueqian Normal University, Xi'an 710100, China \\ 3 The Key Laboratory of Se-Enriched Products Development and Quality Control, Ministry of Agriculture, \\ Ankang 725000, China \\ 4 Hainan Engineering Center of Coconut Further Processing, Coconut Research Institute of Chinese Academy \\ of Tropical Agricultural Sciences, Wenchang 571339, China \\ * Correspondence: zyl_wj_sxsfdx@163.com
}

Citation: Wang, J.; Wang, G.; Zhang, Y.; Zhang, R.; Zhang, Y. Novel Angiotensin-Converting Enzyme Inhibitory Peptides Identified from Walnut Glutelin-1 Hydrolysates: Molecular Interaction, Stability, and Antihypertensive Effects. Nutrients 2022, 14, 151. https://doi.org/ 10.3390/nu14010151

Academic Editors: Sathish Kumar Natarajan, Jiujiu Yu and Corrine K. Hanson

Received: 26 November 2021 Accepted: 25 December 2021 Published: 29 December 2021

Publisher's Note: MDPI stays neutral with regard to jurisdictional claims in published maps and institutional affiliations.

Copyright: (c) 2021 by the authors. Licensee MDPI, Basel, Switzerland. This article is an open access article distributed under the terms and conditions of the Creative Commons Attribution (CC BY) license (https:// creativecommons.org/licenses/by/ $4.0 /)$.

\begin{abstract}
In recent years, angiotensin-converting enzyme (ACE) inhibitory peptide has become a research hotspot because of its essential role in maintaining human blood pressure balance. In this study, two novel ACE inhibitory peptides of Val-Glu-Arg-Gly-Arg-Arg-lle-Thr-Ser-Val (ValineGlutamate-Arginine-Glycine-Arginine-Arginine-Isoleucine-Threonine-Serine-Valine, VERGRRITSV) and Phe-Val-Ile-Glu-Pro-Asn-Ile-Thr-Pro-Ala (Phenylalanine-Valine-Isoleucine-Glutamate-ProlineAsparagine-Isoleucine-Threonine-Proline-Alanine, FVIEPNITPA) were isolated and purified from defatted walnut meal hydrolysates through a series of preparation processes including ultrafiltration, Sephadex G-15 gel chromatography, and reverse high performance liquid chromatography (RPHPLC). Both peptides showed high ACE inhibitory activities. The molecular docking study revealed that VERGRRITSV and FVIEPNITPA were primarily attributed to the formation of strong hydrogen bonds with the active pockets of ACE. The binding free energies of VERGRRITSV and FVIEPNITPA with ACE were -14.99 and $-14.69 \mathrm{kcal} / \mathrm{mol}$, respectively. Moreover, these ACE inhibitory peptides showed good stability against gastrointestinal enzymes digestion and common food processing conditions (e.g., temperature and $\mathrm{pH}$, sugar, and salt treatments). Furthermore, animal experiment results indicated that the administration of VERGRRITSV or FVIEPNITPA exhibited antihypertensive effects in spontaneously hypertensive rats. Our results demonstrated that walnut could be a potential source of bioactive peptides with ACE inhibitory activity.
\end{abstract}

Keywords: walnut glutelin-1; ACE inhibitory peptides; purification; molecular docking; antihypertensive effect

\section{Introduction}

Walnut (Juglans regia L.) is known as one of the world's famous "four dried fruits" together with almonds, cashews, and hazelnuts. It has a long history of cultivation and a large planting area in China. At present, edible oil extraction is the main processing method for walnut kernels.

Walnut meal is an essential by product in the walnut processing industry, and it contains a variety of nutrients, is rich in protein (40-50\%) and essential amino acids [1]. However, walnut meal and related products have limited market acceptance due to their bitter and astringent taste, so most are simply processed and used as fertilizers, or even directly discarded as waste. This processing method wastes high-quality protein resources and pollutes the natural environment [2]. Therefore, making full use of walnut protein and 
developing high value-added products is of great significance to improve the level of deep processing and comprehensive utilization of this raw material.

Hypertension is a significant risk factor for heart diseases, stroke, arteriosclerosis, and other diseases. This condition threatens the health of approximately $20 \%$ of adults worldwide [3,4]. Studies have shown that angiotensin-converting enzyme (ACE) is a central factor of the renin-angiotensin system and kallikrein-kinin system, and plays a crucial role in increasing blood pressure (BP) $[5,6]$. Therefore, inhibiting the ACE's activity has become one of the most effective methods to control blood pressure. Several antihypertensive drugs are designed based on the mechanism of inhibiting ACE activity. Many chemically synthesized ACE inhibitors such as captopril, lisinopril, and enalapril, have been widely used to control hypertension. Nevertheless, previous reports show that the long-term use of these drugs usually has serious side effects, such as cough, hyperkalemia, skin rashes, kidney injury, and taste disorders $[7,8]$. Some antihypertensive peptides, derived from natural food, are considered safe for consumption, and their antihypertensive effects are as effective as synthetic drugs but with less or no adverse side effects compared with synthetic ACE inhibitor drugs (as described above) [9-12]. Therefore, more and more food-derived antihypertensive peptides have been researched and reported.

In general, $\mathrm{ACE}$ inhibitory peptides directly bind or indirectly induce conformational changes at enzyme active sites [13]. The molecular interaction between the purified peptide and $\mathrm{ACE}$ is essential to determine the inhibitory activity [14]. Therefore, it is important to identify natural ACE inhibitory peptides from different species and study the interaction with ACE molecules.

At present, the preparation methods of food-derived antihypertensive peptides primarily include microbial fermentation, enzymatic hydrolysis, and gene synthesis [15-17], among which, enzymatic hydrolysis is the most widely used. Although ACE inhibitory peptides derived from walnut protein have been reported in the literature $[18,19]$, no research has been conducted on ACE peptides isolated and purified from the component protein (glutelin-1 hydrolysate). In addition, previous studies primarily focused on the separation, purification, and identification of walnut ACE inhibitory peptides. Very few reports have focused on the mechanism, the effects of lowering blood pressure in rats, the stability of the simulated gastrointestinal (GI) environment, and typical food processing conditions.

For this study, we have prepared glutelin-1 from a walnut meal. After being hydrolyzed by pepsin, the glutelin-1 hydrolysate was separated and purified by membrane separation, gel chromatography, and high-performance liquid chromatography (HPLCMS/MS). Finally, highly active ACE inhibitory peptides could be obtained. The amino acid sequences of the ACE inhibitory peptides were identified through $\mathrm{N}$-terminal sequence analysis. Moreover, we evaluated the antihypertensive effects of walnut glutelin-1 ACE inhibitory peptides in vivo using a spontaneously hypertensive rat (SHR) model. The ACE inhibitory mechanism of the peptide was explored through molecular docking simulation. We have also investigated the stability of walnut glutelin-1 ACE inhibitory peptides under different food processing conditions and simulated GI digestion environments. The outcomes of this study can improve the deep processing and comprehensive utilization of walnuts and provide theoretical and technical references for the research and development of walnut antihypertensive peptides.

\section{Materials and Methods}

\subsection{Materials}

The Grain, Oil and Protein Engineering Laboratory of Shaanxi Normal University (Xi'an, China) provided the defatted walnut meal. ACE (from rabbit lung) and hippurylhistidyl-leucine (HHL) were purchased from Sigma Co., St. Louis, MO, USA. Pepsin $\left(3 \times 10^{3} \mathrm{U} / \mathrm{g}\right)$ was obtained from Solarbio Science \& Technology, Co., Ltd. (Beijing, China). High-performance liquid chromatography grade acetonitrile and trifluoroacetic acid were purchased from Fischer Scientific Co. (Waltham, MA, USA). The enzyme-linked 
immunosorbent assay kit for the detection of ACE, angiotensinogen (AGT), aldosterone (ALD), and Endothelin-1(ET-1) was purchased from Jiangsu Jingmei Biotechnology Co., Ltd. (YanCheng, China). The enzyme-linked immunosorbent assay kit for the detection of Ang II was obtained from Shanghai Kexing Biotechnology Co., Ltd., (Shanghai, China). and the nitric oxide (NO) detection kit was a product of Nanjing Jiancheng Institute of Biological Engineering (Nanjing, China), and other chemical reagents used in the experiment were of analytical grade.

\subsection{Preparation of Glutelin-1 in Degreased Walnut Meal}

The glutelin-1 fractions were prepared according to our previously published method [20]. In short, the walnut meal was degreased using $n$-hexane $(1: 10, \mathrm{~g} / \mathrm{mL})$ for $2 \mathrm{~h}$, then dried, ground, and passed through a mesh sieve. Next, the continuous extraction method was used to extract albumin, globulin, prolamin, glutelin-1, and glutelin-2 in walnut meal with deionized water, $0.4 \mathrm{M} \mathrm{NaCl}, 70 \%(v / v)$ ethanol, 50\% $(v / v)$ glacial acetic acid, and $0.1 \mathrm{M}$ $\mathrm{NaOH}$. After centrifugation, each extract went through dialysis and lyophilization, the final power obtained was stored at $-20^{\circ} \mathrm{C}$ until use.

\subsection{Preparation of Glutelin-1 Hydrolysate}

We prepared glutelin-1 hydrolysate according to our previous method [20]. In short, the pepsin and glutelin-1 solution were mixed at a ratio of 4:100 $(w / v)$. The $\mathrm{pH}$ of the mixture was adjusted to 1.65 with $1 \mathrm{M} \mathrm{HCl}$ and enzymatically hydrolyzed at $45^{\circ} \mathrm{C}$ for $6 \mathrm{~h}$. The reaction was terminated by heating the solution in a $95{ }^{\circ} \mathrm{C}$ water bath for $10 \mathrm{~min}$. Subsequently, the enzymatic hydrolysate was centrifuged at 10,000 rpm/min for $20 \mathrm{~min}$ at $4{ }^{\circ} \mathrm{C}$, and the supernatant was freeze-dried and stored at $-20{ }^{\circ} \mathrm{C}$ for further analysis.

\subsection{Separation and Purification of the ACE-Inhibitory Peptides from Glutelin-1 Hydrolysate}

An ultrafiltration unit (Pellicon XL, Millipore, Billerica, MA, USA) was used to obtain three fractions named A1 with molecular weight (MW) > $5000 \mathrm{Da}$, A2 with MW 3000-5000 Da, and A3 with MW < 3000 Da from the glutelin-1 hydrolysate by an ultrafiltration unit. The fraction with the highest ACE inhibitory activity was sequentially isolated and purified by a Sephadex G-15 gel column $(2.6 \mathrm{~cm} \times 100 \mathrm{~cm}$, Shanghai Huxi Analytical Instrument Factory Co., Ltd., Shanghai, China) and eluted with distilled water at a flow rate of $0.6 \mathrm{~mL} / \mathrm{min}$. Its loading concentration was $100 \mathrm{mg} / \mathrm{mL}$, and the absorbance was measured at $280 \mathrm{~nm}$. Then, with specific conditions, a reversed-phase high-performance liquid chromatography (RP-HPLC) equilibrated with a C18 column $(4.5 \mathrm{~mm} \times 250 \mathrm{~mm}$, Shimadzu Corporation LC-20A, Kyoto, Japan). First, two eluents consisting of solvent A (in distilled water with $0.1 \%(v / v)$ TFA) and solvent B (acetonitrile with $0.1 \%(v / v)$ trifluoroacetate) were eluted linearly at a flow rate of $1.0 \mathrm{~mL} / \mathrm{min}$ for $30 \mathrm{~min}$. The monitoring wavelengths at this stage were $220 \mathrm{~nm}$ and $280 \mathrm{~nm}$, respectively. All fractions' ACE inhibitory activity and peptide content could be determined after being collected and lyophilized.

\subsection{Amino Acid Sequence Analysis of the Purified Peptides}

The amino acid sequences and molecular mass of the purified peptides were determined by Edman degradation using an automatic protein polypeptide sequencer (Shimadzu Corporation, PPSQ-30A, Kyoto, Japan) and a mass spectrometer (Shimadzu Corporation, LC-20AD XR, Kyoto, Japan).

\subsection{Commercially Synthesis of the Identified Peptides}

The synthetic peptides were obtained by a solid phase procedure (KMD Bioscience, TianJin, China) according to the previously known amino acid sequence. They were purified by RP-HPLC-MS/MS (purity $>95 \%$ ) and stored at $-20^{\circ} \mathrm{C}$ for further analysis. 


\subsection{Determination of ACE Inhibitory Activity}

Following a previous method reported by Zheng et al. (2017) [21], we could determine the ACE inhibitory activity of glutelin-1 hydrolysate, separated fractions, active peptides, and all the other samples with $1.0 \mathrm{mg} / \mathrm{mL}$ Captopril as a positive control. The $\mathrm{IC}_{50}$ value (the concentrationof the inhibitory peptide $(\mu \mathrm{M})$ had to inhibit $50 \%$ of the ACE activity) was calculated by linear regression of the curve.

The following formula was used to calculate the ACE inhibition rate (\%):

$$
\text { ACE inhibition rate }(\%)=\left(1-\frac{\mathrm{As}}{\mathrm{Ac}}\right) \times 100
$$

where Ac represents ACE solution's absorbance without an inhibitor and As represents the mixture containing samples.

\subsection{Molecular Docking}

The RCSB Protein Data Bank (https: / / www.rcsb.org, accessed on 2 February 2021) was used to download the crystal structure of the ACE (Protein Data Bank identification (PDB ID): 1O86, Resolution: $2.00 \AA$ ). The peptide structure was processed on the molecular manipulation environment platform (Molecular operating environment (MOE) 2019.1), including steps such as removing water and ions, protonation, addition of missing atoms, and completion of missing groups. Moe I Dock Module was used, and Amber10 was selected as the force field. One hundred conformations were generated after docking, and we selected the most negative conformations using the London DG scoring function. Finally, molecular visualization was processed by Pymol 2.3 software (Schrodinger Inc, NY, New York, USA).

\subsection{Antihypertensive Effect in SHR}

\subsubsection{BP Measurement}

Thirty 10-week-old male spontaneously hypertensive rats (SHRs) and five normal male rats of the same age were used for the experiment. The rats were placed at $25^{\circ} \mathrm{C} \pm 1{ }^{\circ} \mathrm{C}$, relative humidity of $45-55 \%$ and a light/dark cycle for $12 \mathrm{~h}$. SHRs were randomly divided into 6 groups after one week of adaptation, while rats in the normal group (NG) were used as controls. The administration was continued for 28 days.

Rats in the normal and SHR groups were given $1.0 \mathrm{~mL}$ of $0.9 \%$ saline per day, while the positive control group was given captopril $(10 \mathrm{mg} / \mathrm{kg}$ body weight) per day. The ACE inhibitory peptides treatment groups' low and high doses were fed orally with 5 and $15 \mathrm{mg} / \mathrm{kg}$ (based on their body weight) by dissolving the peptides in $1.0 \mathrm{~mL}$ of $0.9 \%$ normal saline. The rats' BP was measured by the tail-cuff method. The systolic blood pressure (SBP), diastolic blood pressure (DBP), and heart rate of all rats were measured after a single oral administration $(0-8 \mathrm{~h})$ and weekly $(0-4$ weeks). All measurements were repeated at least three times so the average value could be calculated.

\subsubsection{Assay for Serum ET-1, NO, ACE, Ang II, AGT, and ALD in SHR Rats}

The upper serum samples were obtained by centrifugation at $3000 \times \mathrm{g}$ at $4{ }^{\circ} \mathrm{C}$ for $10 \mathrm{~min}$ after the blood was taken from the abdominal aorta of all rats. The samples were stored at $-20{ }^{\circ} \mathrm{C}$, and the serum expression was detected using the ELISA kit (double antibody sandwich enzyme-linked immunosorbent assay).

\subsection{Stability of the Synthetic Peptides}

\subsubsection{GI Digestion Stability Analysis of the Synthesized Peptides}

We conducted a GI digestion stability analysis of the synthesized peptides according to the method proposed by Khueychai et al. (2018) [5] with slight modifications. Briefly, the peptide solution was incubated with $1 \mathrm{mg} / \mathrm{mL}$ of pepsin solution $(0.1 \mathrm{M} \mathrm{HCl}, \mathrm{pH} 2.0)$ at $37^{\circ} \mathrm{C}$ for $3 \mathrm{~h}$. Subsequently, the $\mathrm{pH}$ value of the mixed solution was adjusted to 8.0 with $1.0 \mathrm{M} \mathrm{NaOH}$, and $1.0 \mathrm{mg} / \mathrm{mL}$ of trypsin added and incubated at $37^{\circ} \mathrm{C}$ for $4 \mathrm{~h}$. Finally, 
the ACE inhibitory activity of the reaction solution could be determined after boiling for $10 \mathrm{~min}$, cooling to room temperature, and centrifuging for $15 \mathrm{~min}$ at $10,000 \times \mathrm{g}$.

2.10.2. Temperature, $\mathrm{pH}$, Metal Ion, Sugar, and Salt Treatments Stabilities of the Synthesized Peptides

The effect of temperature, $\mathrm{pH}$, metal ion, sugar, and salt treatments on the stabilities of two synthesized peptides, were determined by incubating $1.0 \mathrm{mg} / \mathrm{mL}$ of VERGRRITSV and FVIEPNITPA at $20^{\circ} \mathrm{C}, 40^{\circ} \mathrm{C}, 60^{\circ} \mathrm{C}, 80^{\circ} \mathrm{C}$, and $100{ }^{\circ} \mathrm{C}$ for $2 \mathrm{~h} ; 37^{\circ} \mathrm{C}$ for $2 \mathrm{~h}$ at $\mathrm{pH} \mathrm{2,4,6}$, 8, and 10; with $100 \mu \mathrm{g} / \mathrm{mL}$ of $\mathrm{KCl}, \mathrm{CaCl}_{2}, \mathrm{ZnSO}_{4}, \mathrm{MgSO}_{4}$, and $\mathrm{FeSO}_{4}$ solution at $37^{\circ} \mathrm{C}$ for $2 \mathrm{~h}$; with glucose solutions of $2 \%, 4 \%, 8 \%$, and $12 \%$ at $37{ }^{\circ} \mathrm{C}$ for $30 \mathrm{~min}$; with $\mathrm{NaCl}$ solutions of $2 \%, 4 \%, 8 \%$, and $12 \%$ at $37{ }^{\circ} \mathrm{C}$ for $30 \mathrm{~min}$, respectively. The ACE inhibition rate was measured immediately after incubation.

\subsection{Statistical Analyses}

Each experiment had to be repeated at least three times, and the results were expressed as mean \pm SD. One-way analysis of variance (ANOVA) was used to analyze the significant difference between the groups ( $p<0.05$ ). GraphPad Prism 6.0 (San Diego, CA, USA) and Microsoft Office programs, including Word and Excel, were used for statistical analysis and pictures drawing.

\section{Results and Discussion}

\subsection{Isolation and Purification of ACE Inhibitory Peptides of Glutelin-1 Hydrolysate}

As shown in Figure 1, glutelin-1 hydrolysate was divided into three fractions through ultrafiltration membranes with molecular weight cut-offs of 5 and $3 \mathrm{kDa}$. The fractions were labeled as $\mathrm{A} 1(\mathrm{MW}>5 \mathrm{kDa}), \mathrm{A} 2(3<\mathrm{MW}<5 \mathrm{kDa})$, and $\mathrm{A} 3(\mathrm{MW}<3 \mathrm{kDa})$. Among the three fractions, A3 (MW < $3 \mathrm{kDa})$ showed the highest ACE inhibitory activity $(62.25 \% \pm 1.54 \%)$, which was significantly higher than the glutelin-1 hydrolysate before ultrafiltration separation $(50.91 \% \pm 2.65 \%, p<0.01)$.

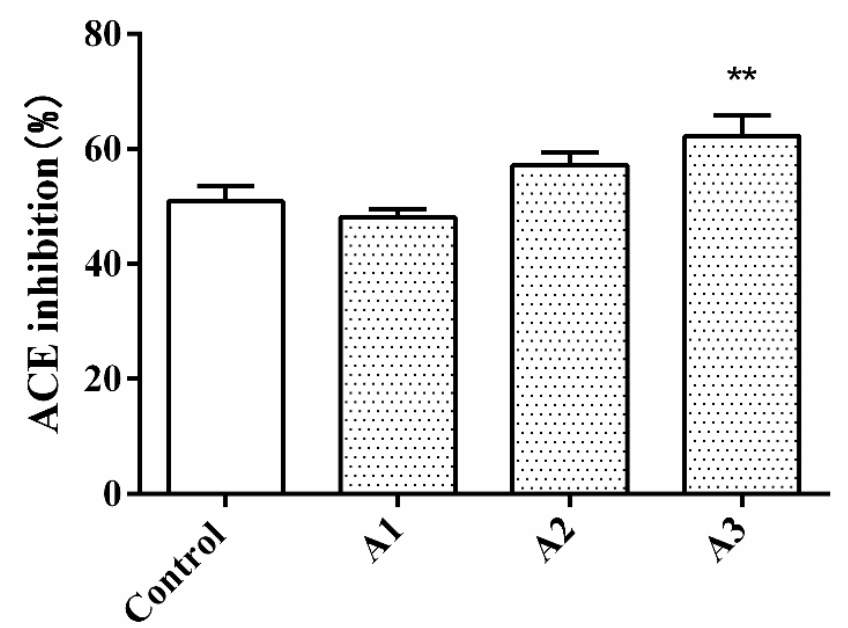

Figure 1. Angiotensin-converting enzyme (ACE) inhibitory rates of ultrafiltration fractions of glutelin1 hydrolysates of walnut at the concentration of $1.0 \mathrm{mg} / \mathrm{mL}$. Control: Glutelin- 1 hydrolysate before separation and purification. All data are presented as the mean $\pm \mathrm{SD}$ of triplicate results. ${ }^{* *} p<0.01$, vs. the control, A1-A3 represent the three fractions obtained after ultrafiltration separation, A1 (MW $>5 \mathrm{kDa}), \mathrm{A} 2(3<\mathrm{MW}<5 \mathrm{kDa})$ and $\mathrm{A} 3(\mathrm{MW}<3 \mathrm{kDa})$.

Many studies have found a specific correlation between the molecular weight of peptides and ACE inhibitory activity. Low molecular weight (less than $3 \mathrm{kDa}$ ) peptides often had higher ACE inhibitory activity [22]. Our research results also indicated that the ACE inhibitory activity might be related to the size of the peptide. 
The A3 fraction was divided into four main fractions by Sephadex G-15 gel chromatography (Figure 2A). The ACE inhibitory activity of these four subfractions was significantly higher than that of the glutelin-1 hydrolysate $(p<0.01)$ (Figure 2B). In addition, fraction B2 showed higher ACE inhibitory activity $(84.22 \% \pm 1.84 \%)$ compared to the others, fraction B2 was again separated by RP-HPLC (Figure 3A). Ten major fractions labeled as P1-P10 were collected (Figure 3B). P5 and P8 displayed the highest ACE inhibitory activity (Figure 3C). RP-HPLC further purified these two fractions in an analytical C18 column, and later amino acid sequencing was performed.

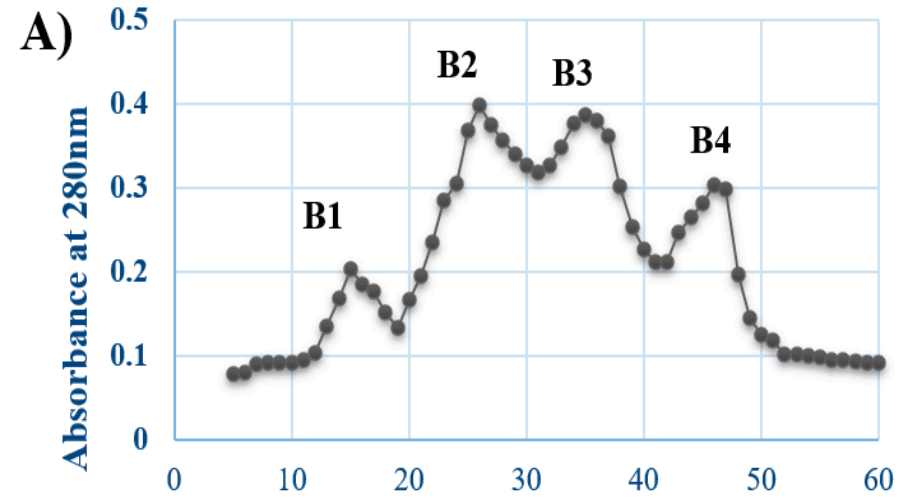

Tube number

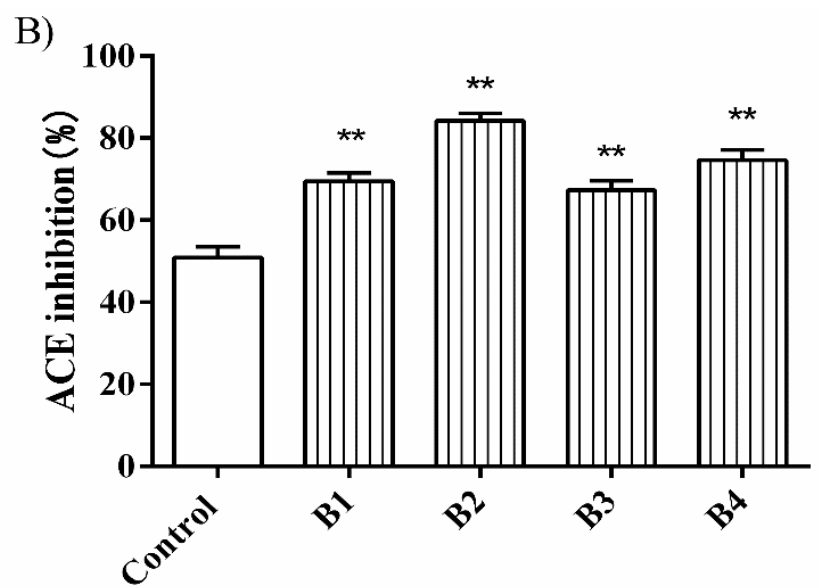

Figure 2. Sephadex G-15 gel chromatography separation of A3 (A) and ACE inhibitory rates of subfractions from $\mathrm{A} 3$ at the concentration of $1.0 \mathrm{mg} / \mathrm{mL}(\mathbf{B})$. Control: Glutelin-1 hydrolysate before separation and purification. All data are presented as the mean \pm SD of triplicate results. ${ }^{* *} p<0.01$, vs. the control, B1-B4 represent the four fractions separated by Sephadex G-15 gel chromatography.

\subsection{Peptide Identification and Synthesis}

The amino acid sequences of peptides P5 and P8 that showed the highest ACE inhibitory activity peptides, were analyzed using the Edman degradation method. As shown in Table 1, P5 was identified as Val-Glu-Arg-Gly-Arg-Arg-lle-Thr-Ser-Val (VERGRRITSV) with a molecular weight of $1172.35 \mathrm{Da}$. P8 was identified as Phe-Val-Ile-Glu-Pro-Asn-IleThr-Pro-Ala (FVIEPNITPA) with a molecular weight of 1100.28 Da (Table 1). The two peptides were identified from walnut protein hydrolysate, and we did not find previous reports regarding this phenomenon. According to amino acid sequence results, the two peptides (VERGRRITSV and FVIEPDITPA) were synthesized via a solid-phase process to evaluate the ACE inhibitory activity. The ACE inhibitory peptides identified in this study had vigorous activity. VERGRRITSV and FVIEPNITPA displayed $\mathrm{IC}_{50}$ values of $6.82 \mu \mathrm{M}$ and $6.36 \mu \mathrm{M}$, respectively.

Table 1. Amino acid sequences, molecular weights, and IC 50 values on angiotensin converting enzyme (ACE) of walnut glutelin-1 hydrolysate ACE inhibitory peptides.

\begin{tabular}{ccccc}
\hline Fraction & Retention Time (Min) & $\begin{array}{c}\text { Amino Acid } \\
\text { Sequence }\end{array}$ & Mass (Da) & IC $\mathbf{5 0}^{(\mu M)}$ \\
\hline P5 & 16.120 & $\begin{array}{c}\text { Val-Glu-Arg-Gly-Arg-Arg-Ile-Thr-Ser-Val } \\
\text { (VERGRRITSV) }\end{array}$ & 1172.35 \\
P8 & 17.635 & $\begin{array}{c}\text { Phe-Val-Ile-Glu-Pro-Asn-Ile-Thr-Pro-Ala } \\
\text { (FVIEPNITPA) }\end{array}$ & 1100.28 \\
\hline
\end{tabular}



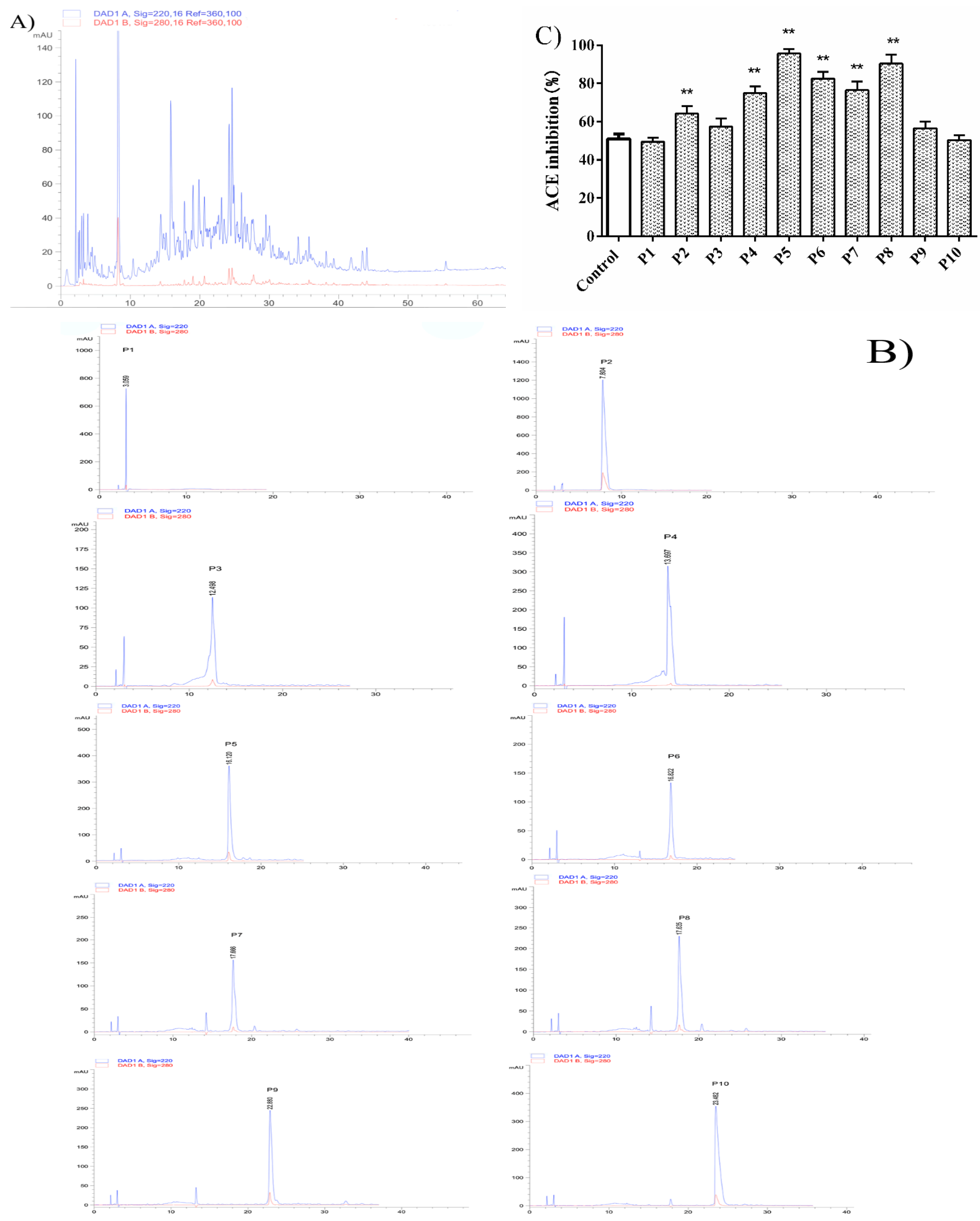

Figure 3. Chromatography of fraction B2 separated by RP-HPLC (Reverse high performance liquid chromatography) on a Shimadzu C18 column $(5 \mu \mathrm{m}, 4.6 \times 250 \mathrm{~mm})$ using a linear gradient of acetonitrile (20-100\% in 0-25 $\mathrm{min}$ ) in $0.1 \%$ TFA at a flow rate of $1.0 \mathrm{~mL} / \mathrm{min}(\mathbf{A})$. Fractions P1-P10 (B). 
ACE inhibition activity of fractions P1-P10 (C) were separately isolated by analytical RP-HPLC. Control: Glutelin-1 hydrolysate before separation and purification. ${ }^{* *} p<0.01$, vs. the control. P1-P10 represent 10 major fractions obtained after separation by RP-HPLC.

Previous studies have evidenced that the ACE inhibitory activity of peptides is primarily related to molecular weight, hydrophobicity, amino acid composition, and peptide sequence [23]. Most of the reported competitive ACE inhibitory peptides usually have a molecular weight of less than $3 \mathrm{kDa}$ and contain 2-12 amino acids. These short peptides interact with the ACE protein by competing for the active site of action [24]. The two peptides reported in this paper were similar. In addition, many studies found that the amino acid sequence of the peptide correlated with the ability to inhibit ACE activity. Many studies have shown that ACE inhibitory peptides usually have hydrophobic amino acid residues at the $\mathrm{C}$-terminal or $\mathrm{N}$-terminal sites $[8,19]$. When the $\mathrm{N}$-terminal contains a hydrophobic amino acid, such as valine $(\mathrm{V})$, phenylalanine $(\mathrm{F})$, leucine $(\mathrm{L})$, isoleucine (I), or a basic amino acid, the ACE activity is generally high. The higher ACE inhibitory activity of the pure peptide FVIEPNITPA might be related to its N-terminal containing 3 hydrophobic amino acids. Many peptides with high ACE activity contain valine at the N-terminal, such as VKPLPQSG, VAMPF, VPP, and VIIF $[23,25,26]$. Some antihypertensive peptides containing proline $(\mathrm{P})$, valine $(\mathrm{V})$, or phenylalanine $(\mathrm{F})$ at the $\mathrm{C}$-terminal sites showed high ACE inhibitory activity. Our results also support this idea. The C-terminal and N-terminal hydrophobic amino acids were indeed involved in the expression of ACE inhibitory activity. The high ACE inhibitory activity of VERGRRITSV identified in this study may be related to the $\mathrm{N}$-terminal and $\mathrm{C}$-terminal amino acids (Val). However, the ACE inhibitory peptides' structure-activity relationship was not analyzed thoroughly.

\subsection{Molecular Docking Simulation}

The interactions between the two purified bioactive peptides (VERGRRITSV and FVIEPNITPA) and ACE were characterized by molecular docking technology. As an important thermodynamic property, binding free energy is usually calculated with a biological system model [27]. As it can be inferred from the results of the lowest free energy between ACE and the two bioactive peptides shown in the molecular simulation docking model (Figure 4), both peptides could interact with ACE to form an ACE-ligand complex. The lower binding free energies $(-14.99$ and $-14.69 \mathrm{kcal} / \mathrm{mol}$ for VERGRRITSV and FVIEPNITPA, respectively) indicated a high binding affinity between the peptides and the molecular ACE, which might be due to the existence of a large number of hydrogen bonds, hydrophobicity, electrostatic force and van der Waals. This possibility is valid, especially for the hydrogen bond, since it has been widely proved that it plays a vital role in maintaining the stability of ligand complexes $[13,28]$. For instance, multiple hydrogen bond interactions between peptides and ACE can increase the inhibition activity on ACE by stabilizing the structure of the non-catalytic enzyme-peptide complex [29]. In addition, the number of hydrogen bonds was often positively correlated with the interaction between peptides and ACE [14]. VERGRRITSV formed nine hydrogen bonds with residues Lys511, Gln281, Glu376, Glu162, Ala354, Tyr523, Glu411, ser516, and Glu403 and eight salt bridges with residues Glu376, His353, Asp377, His387, Glu411, Glu143, ser516, and Zn701 in ACE (Figure 4B). FVIEPNITPA established seven hydrogen bonds with residues Asn374, Glu376, Glu162, Ala354, Ala356, ser516, and Glu143 and two salt bridges with Zn701 and Arg522 in ACE (Figure 4D). It has previously been demonstrated that S1 with Tyr523, Glu384, and Ala354 residues, S2 with Tyr520, His513, Lys511, His353, and Gln281 residues, and S1 with Glu162 residue are the three main active site pockets of ACE $[23,30]$. Molecular docking results showed that the two bioactive peptides had different binding sites with ACE. VERGRRITSV could bind to ACE through S1, S2, and S1 pockets by the Ala354 and Tyr523 residues, Gln281, His353, and Lys511 residues, and Glu162 residue, respectively. FVIEPNITPA interacted with ACE though two pockets of S1 in Ala354 residue and $\mathrm{S} 1$ in Glu162 residue. These outcomes indicate that the strong interaction between VERGRRITSV and ACE may lead to great inhibitory activity. The ACE-ligand complex 
formed by docking was more stable than FVIEPNITPA. Besides, ACE's active site was usually tetrahedral, which resulted from the coordination of zinc ions $\left(\mathrm{Zn}^{2}\right)$ with Glu411, His387, and His383 [31]. VERGRRITSV and FVIEPNITPA might also compete with ACE to bind zinc ions, thereby destroying ACE's active site and improving ACE inhibitory activity.

A)

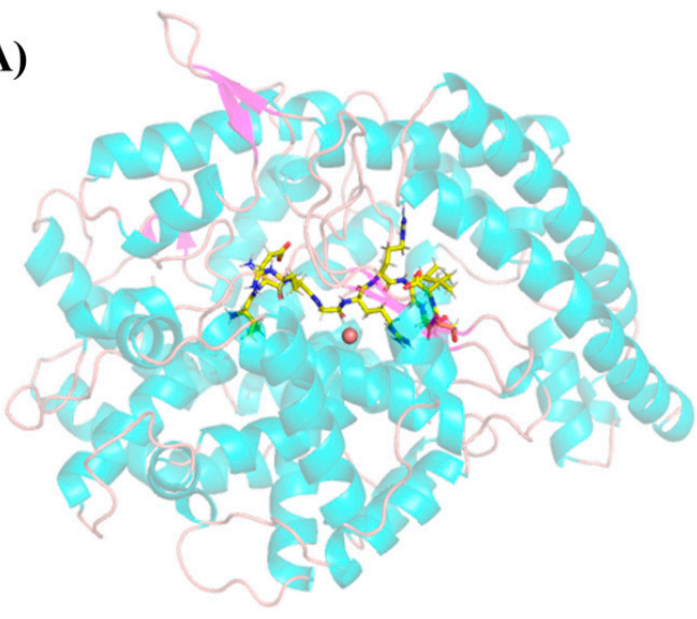

B)

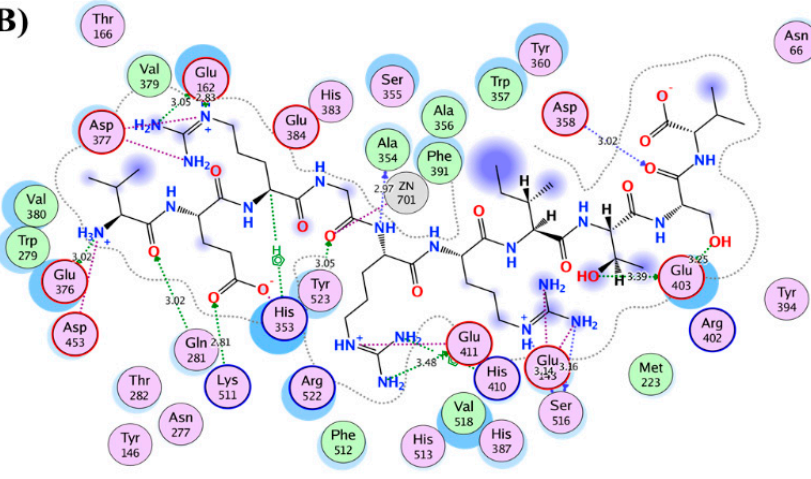

C)

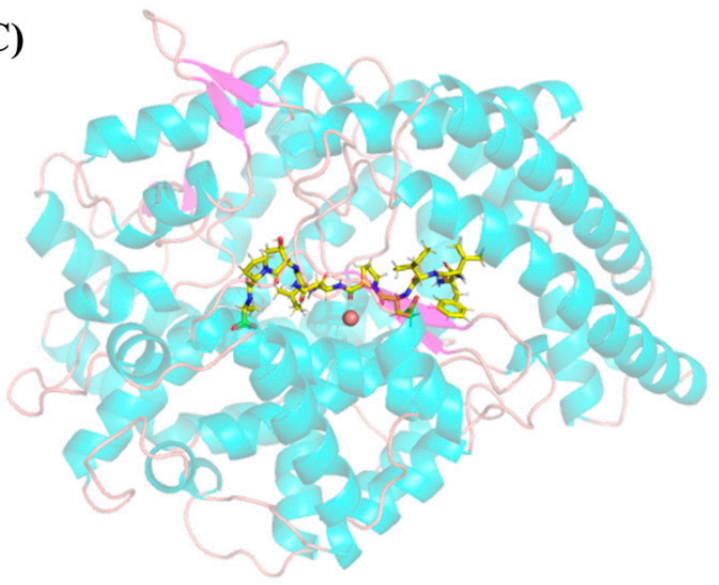

D)
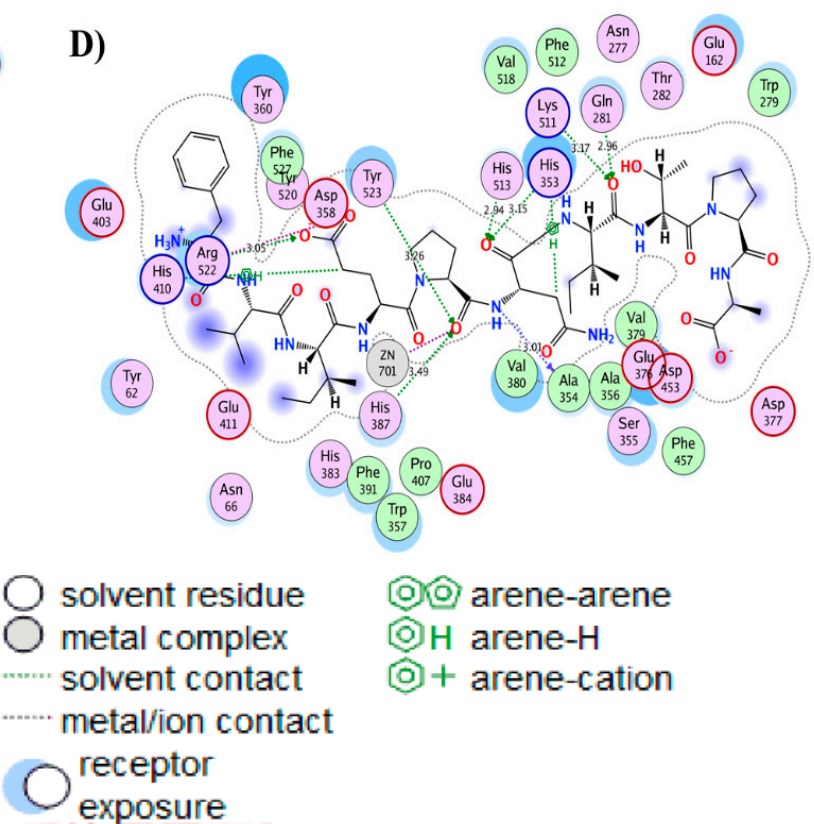

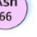

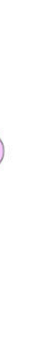

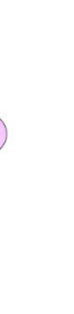

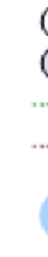

exposure

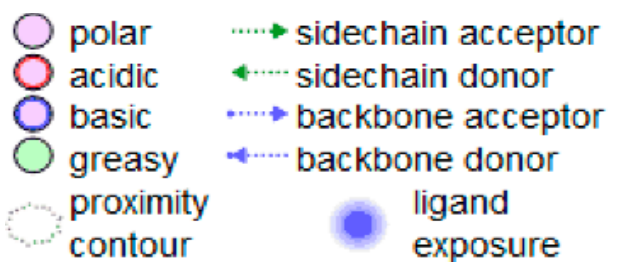

Figure 4. The best binding conformation of the pure peptides with ACE (PDB: 1O8A). 3D diagram of VERGRRITSV (A), 2D diagram of VERGRRITSV (B), 3D diagram of FVIEPDITPA (C), 2D diagram of FVIEPDITPA (D).

\subsection{Antihypertensive Effect in SHR}

3.4.1. Effect of Oral Administration of Glutelin-1 ACE Inhibitory Peptide on SBP and DBP in SHR

It has previously been reported that some ACE inhibitory peptides have good inhibitory activity in vitro. However, the antihypertensive effect in vivo is not so evident, and some ACE inhibitory peptides actually have the opposite effect $[15,32,33]$. Walnut glutelin-1 ACE inhibitory peptides (VERGRRITSV and FVIEPNITPA) showed high inhibitory activity in vitro. However, animal experiments still need to verify whether they also have a blood pressure lowering activity in vivo. The antihypertensive effects of two ACE inhibitory peptides (VERGRRITSV and FVIEPNITPA) in vivo were evaluated by 
measuring the changes of SBP and DBP.As shown in Figure 5A, the SBP of SHR in each group, before administration, reached approximately $170-180 \mathrm{mmHg}$. After a single intragastric administration experiment, the SBP of the treatment group decreased rapidly in the first 0-2 h. The maximal reduction in SBP of the captopril-treated, VERGRRITSV-treated (VERGRRITSV-H, and VERGRRITSV-L), and FVIEPNITPA-treated (FVIEPNITPA-H and FVIEPNITPA-L) groups reached 29.5, 32.3, 22.4, 30.4, and $23.0 \mathrm{mmHg}$, respectively. The SBP of the captopril group and low-dose ACE inhibitory peptide group remained basically stable for 2-8 h. The high-dose ACE inhibitory peptide group showed a slow and continuous decline, while the SBP of the high-dose ACE inhibitory peptide group continued to decrease slowly. Eight hours after administration, the SBP of the high-dose ACE inhibitory peptide groups dropped to approximately $140 \mathrm{mmHg}$. It can be concluded from the results that the purified ACE inhibitory peptides could reduce SBP after a single administration.

It can be seen from Figure 5B that the SBP of the SHRs negative control group showed an evident increasing trend during the 4-week experiment. After one week of oral administration, the SBP of the captopril positive control group and the ACE inhibitory peptides (VERGRRITSV and FVIEPNITPA) treatment groups were significantly lower than that of the SHRs group $(p<0.01)$. In the first week, the SBP of the VERGRRITSV-L-treated group decreased from $175.3 \pm 10.1 \mathrm{mmHg}$ to $137.7 \pm 8.2 \mathrm{mmHg}$; the SBP remained basically stable in the following three weeks.

The DBP of the SHR control group increased rapidly over time, and it was significantly higher than that of the other groups in the second week after administration $(p<0.01)$. On the contrary, the DBP of the captopril, low-dose ACE inhibitory peptide VERGRRITSV, and FVIEPNITPA groups began to decrease after one week of continuous administration, and the decline reached a maximum in the second week. The DBP of the high-dose ACE inhibitory peptide FVIEPNITPA group began to decrease in the second week after administration. Besides, the high-dose ACE inhibitory peptide VERGRRITSV could inhibit the rapid increase in DBP, but its DBP did not decrease (Figure 5C). Our research results clearly show that the ACE inhibitory peptides (VERGRRITSV and FVIEPNITPA) had good effects on reducing the BP level in vivo. Additionally, the low-dose VERGRRITSV group had a better effect than other treatment groups. The results clearly verified that the ACE inhibitory peptides (VERGRRITSV and FVIEPNITPA) of walnut glutelin-1 could significantly reduce blood pressure of SHRs and have great potential in developing functional foods or antihypertensive drugs.

3.4.2. Effects of Glutelin-1 ACE Inhibitory Peptide on Serum ACE, AngII, AGT, and ALD Levels in SHR

The renin-angiotensin system (RAS) is a vital body fluid system of the human body. Renin secreted by the parabulbar cells in the glomerulus enters the bulbar artery and can catalyze AGT conversion into angiotensin I (AngI). AngI then produces AngII, which has a solid hypertension-increasing effect under the influence of ACE [34]. AngII can cause the smooth muscle of the blood vessel to contract, increasing the BP level. It also increases ALD secretion, which can boost the reabsorption of sodium in the kidneys' proximal tubules and cause the retention of sodium and water. As a consequence, the blood sodium concentration and BP levels may surge [10]. As shown in Figure 6A-D, the levels of AGT, ACE, AngII, and ALD in the serum of the SHR control group were significantly higher than those of the captopril-treated, VERGRRITSV-treated, and FVIEPNITPA-treated groups $(p<0.05)$. These findings demonstrated that the walnut glutelin-1 ACE inhibitory peptide could inhibit the ACE activity and over-activated RASS, thereby reducing the production of AngII, preventing the excessive secretion of ALD, slowing the reabsorption of sodium by the kidneys, and lowering BP levels of SHRs. 

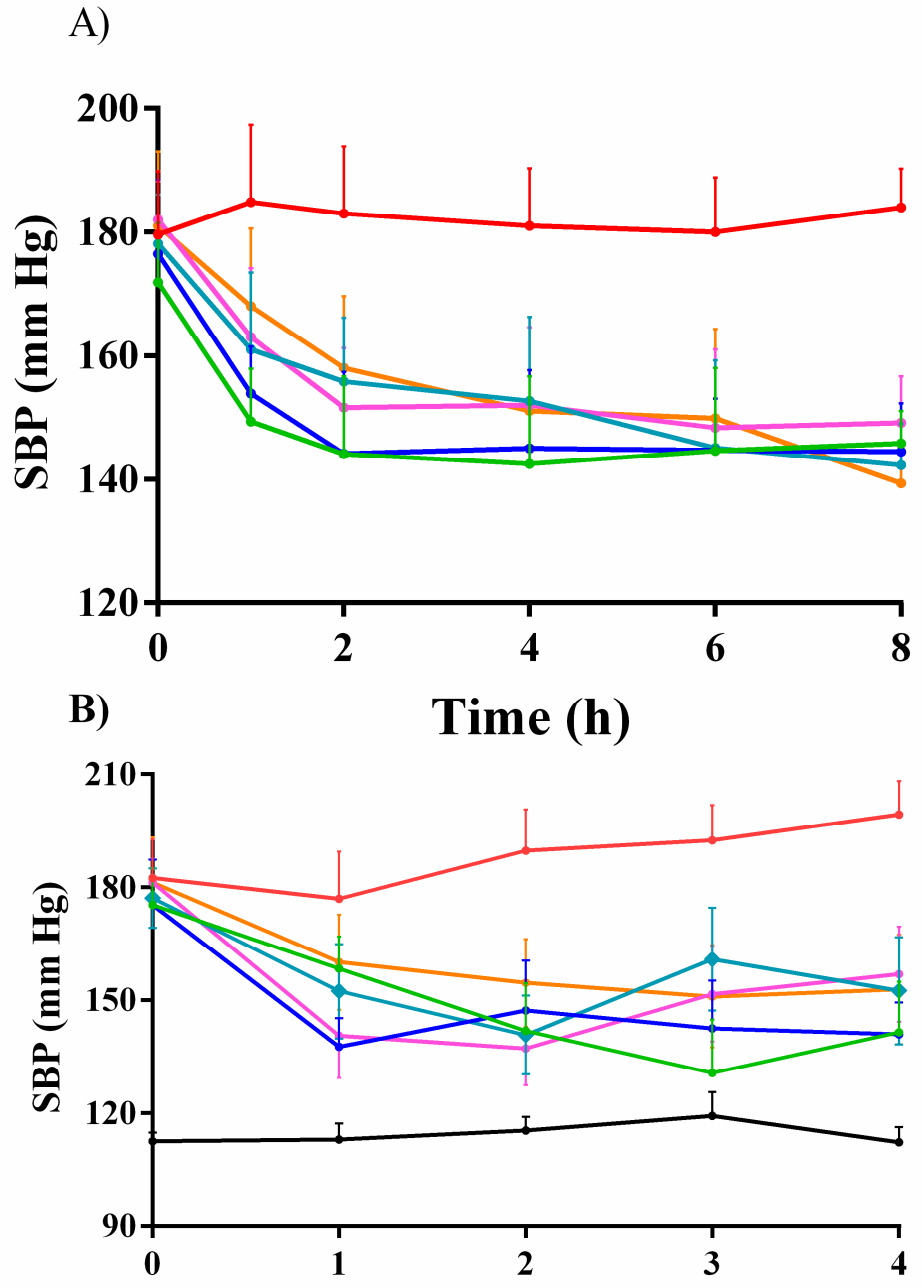

C) Time (week)

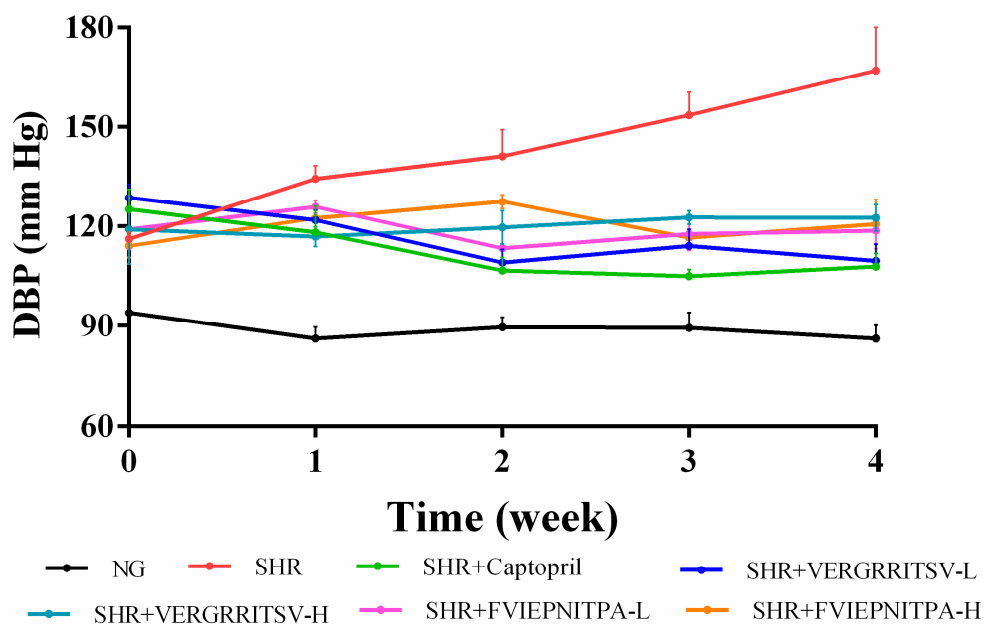

Figure 5. Effect of single oral administration (0-8 h) on SBP in SHRs (A); four weeks oral administration on SBP (B), and DBP in SHRs (C). NG represents rats in the normal group.

3.4.3. Effects of the ACE Inhibitory Peptide of Walnut Glutelin-1 on Serum ET-1 and NO Levels in SHR

The balance of NO and ET-1 synthesis and release is the key to maintaining vascular endothelium's normal function. ET-1 is considered a potent vasoconstrictor secreted by endothelial cells [35]. NO can relax blood vessels, and it has anti-inflammatory, anti-platelet, anti-proliferative, and anti-migration features, playing a central role in the development of 
endothelial function [36]. The lack of NO produced by endothelial nitric oxide synthase leads to endothelial dysfunction. During hypertension, ACE catalyzes the degradation of bradykinin in the kallikrein system. The dysfunction of the vascular endothelial function leads to an insufficient release of NO synthesis and can increase the release of ET-1 synthesis, resulting in vasoconstriction and surging BP levels [37]. As shown in Figure 6E-F, the content of ET-1 in the serum of the SHR control was significantly higher than that of the other groups $(p<0.01)$, and the NO content was significantly lower than that of the treated groups $(p<0.05)$. In addition, the VERGRRITSV and FVIEPNITPA-treated groups had low ET-1 levels, and the NO content was equivalent to that of the captopril group. Therefore, the walnut glutelin-1 ACE inhibitory peptide could decrease the activity of ACE, slow down the degradation of bradykinin, improve the function of vascular endothelium, and regulate the vasomotor state effectively, consequently lowering the BP level.

A)

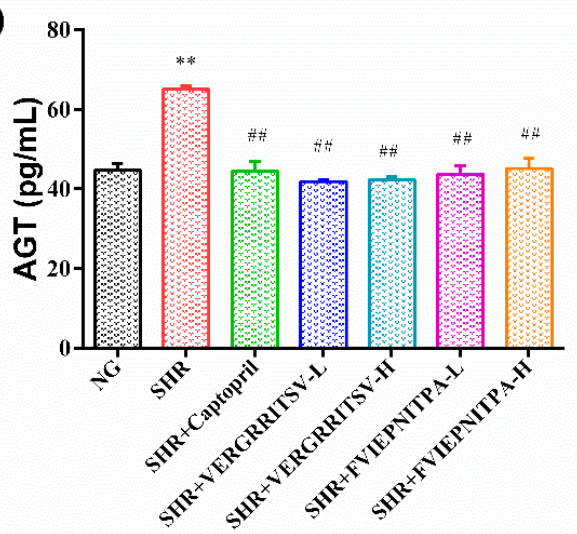

C)

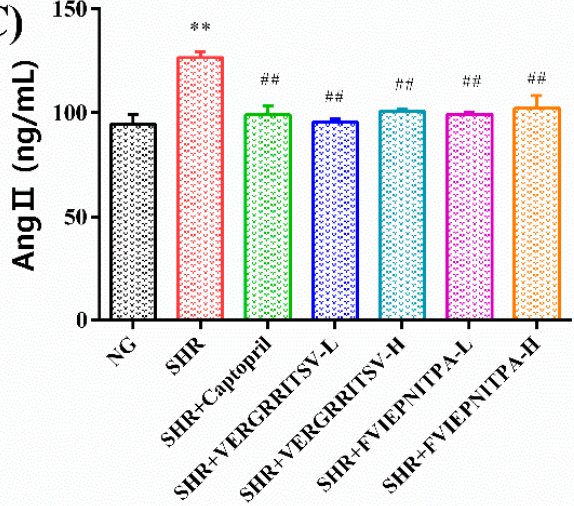

E)

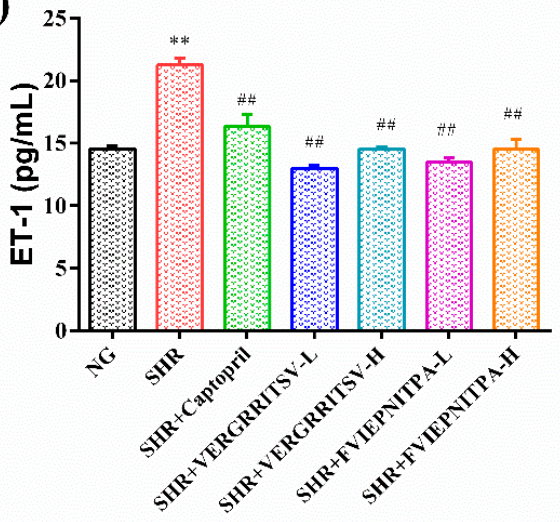

B)

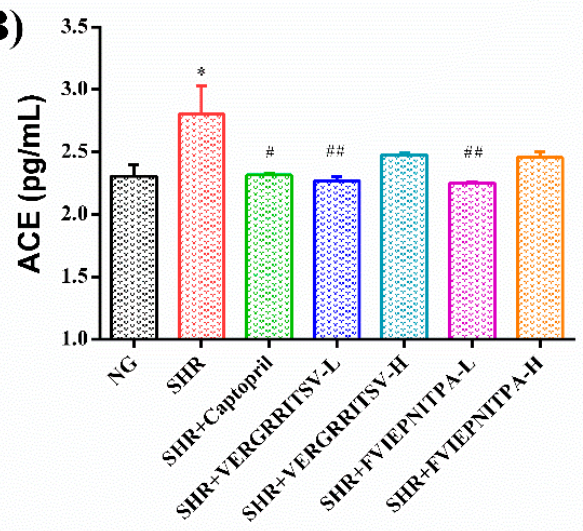

D)

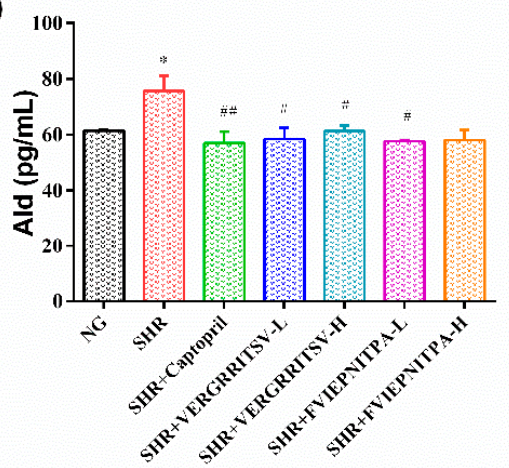

F)

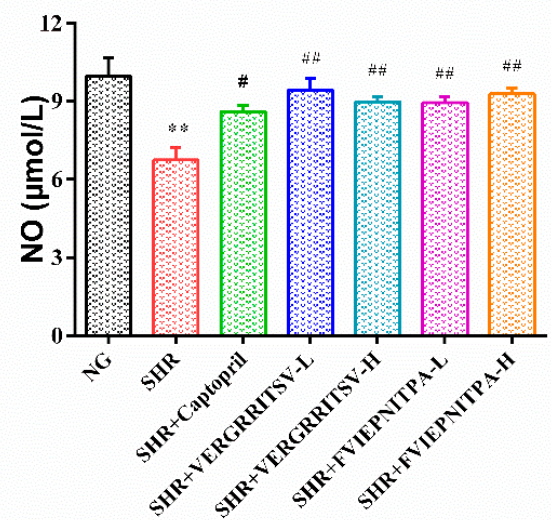

Figure 6. Effects of ACE inhibitory peptides of walnut glutelin-1 on serum AGT (A), ACE (B), Ang II (C), ALD (D), ET-1 (E), and NO (F) levels in SHR. ${ }^{*} p<0.05$ and ${ }^{* *} p<0.01$, vs. the normal group (NG). ${ }^{\#} p<0.05$ and ${ }^{\# \#} p<0.01$ compared with the SHRs group. 


\subsection{Stability of Synthetic Peptides \\ 3.5.1. Effect of In Vitro GI Digestion}

After entering the human digestive system, the peptides are degraded by digestive enzymes in the GI tract, which have uncertain effects on the spatial structure, amino acid sequence, molecular weight and other aspects of ACE inhibitory peptides [38]. Therefore, some ACE inhibitory peptides with high in vitro activity decreased in vivo activity. However, some other peptides exhibited the opposite behavior [39,40]. It was necessary to verify whether ACE inhibitory peptides can resist the hydrolysis of digestive proteases [41]. The digestibility of the walnut glutelin-1 ACE inhibitor peptide in pepsin and trypsin could be determined by simulating the intestinal digestion environment of gastric juice in vitro. As shown in Figure 7A, the ACE inhibitory peptides (VERGRRITSV and FVIEPNITPA) could still maintain high ACE inhibitory activity under pepsin or trypsin digestion. However, after the combined action of pepsin and trypsin, the ACE inhibitory activity decreased considerably, and the inhibition rate of VERGRRITSV and FVIEPNITPA was reduced to 76.9 and 70.3, respectively. This might be due to the active peptides serving as substrates in the GI tract and were partially hydrolyzed into short peptides, or even amino acids by digestive enzymes, which directly affects the structure of peptides and the ACE inhibitory activity $[39,40]$.

\subsubsection{Effect of Temperature, $\mathrm{pH}$, Metal Ion, Sugar, and Salt Treatments}

Some environmental factors during food processing, such as temperature, $\mathrm{pH}$, metal ions, salt concentration and sugar concentration, will affect the stability of ACE inhibitory peptides and determine their potential applicability in functional foods [41].The influence of food processing environmental factors on walnut meal glutelin-1 ACE inhibitory peptides (VERGRRITSV and FVIEPNITPA) showed that the ACE inhibitory peptide activity of walnut glutelin-1 did not change much between $20^{\circ} \mathrm{C}-60^{\circ} \mathrm{C}$ (Figure 7B). However, higher temperatures could decrease the ACE inhibitory activity. The ACE inhibition rates remained above $80 \%$ at $80{ }^{\circ} \mathrm{C}$ and dropped to about $70 \%$ at $100{ }^{\circ} \mathrm{C}$, possibly because ACE inhibitory peptides would be degraded and change in structure at higher temperatures [42].

The change of $\mathrm{pH}$ value had no significant effect on the activity of walnut glutelin-1 ACE inhibitory peptides (Figure 7C), indicating that the two ACE inhibitory peptides (VERGRRITSV and FVIEPNITPA) had good $\mathrm{pH}$ stability. The two peptides could maintain good activity after being hydrolyzed by pepsin, which may be related to their excellent $\mathrm{pH}$ stability [43]. Some scholars believed that ACE inhibitory peptides were not easily affected by $\mathrm{pH}$ and digestive enzymes, which may be related to their smaller molecular weight $[44,45]$, and our research results may be related to this.

Metal ions directly affected the ACE inhibitory activity of walnut glutelin-1 (Figure 7D). We have observed that ACE inhibitory peptides were very stable in an environment with metal ions such as $\mathrm{K}^{+}, \mathrm{Ca}^{2+}$, and $\mathrm{Mg}^{2+}$, whereas such peptides had poor stability under $\mathrm{Zn}^{2+}$ and $\mathrm{Fe}^{2+}$ conditions. Potassium, calcium, and magnesium are important components of daily food, and walnut glutelin-1 ACE inhibitory peptides can be consumed with foods containing these nutrients without affecting their activity. However, to contain other potential changes in the peptides' activity, food rich in $\mathrm{Zn}^{2+}$ and $\mathrm{Fe}^{2+}$, e.g., animal liver, kidney, blood, lean meat, shellfish, kelp, and fungus should be avoided $[43,46,47]$. 

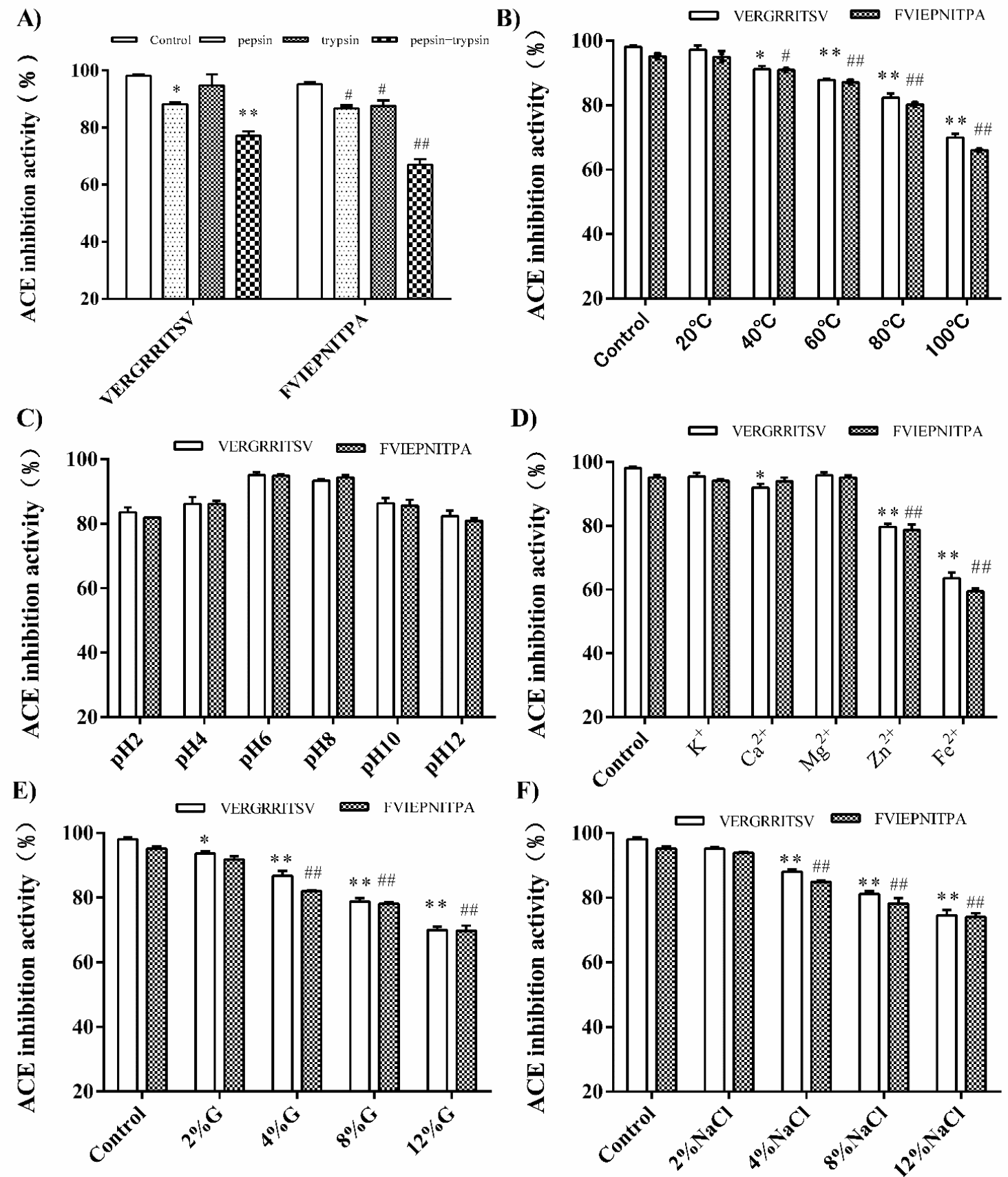

Figure 7. The stability of ACE-inhibitory activity in synthetic peptides VERGRRITSV and FVIEPNITPA exposed to simulated gastrointestinal digestion (A). Effect of temperature (B), $\mathrm{pH}(\mathbf{C})$, metal ions (D), glucose (E), and $\mathrm{NaCl}(\mathbf{F})$ on the stability of synthetic peptides VERGRRITSV and FVIEPNITPA. ${ }^{*} p<0.05$ and ${ }^{* *} p<0.01$, vs. the VERGRRITSV control group. ${ }^{\#} p<0.05$ and ${ }^{\# \#} p<0.01$ compared with the FVIEPNITPA control group.

Glucose is a common preservative that is widely used in food and health products. It also has varying degrees of influence on the color, taste, and flavor of food. Considering that the Maillard reaction occurs when there are reducing sugars and amino compounds in food, it is necessary to study the effect of glucose on the inhibitory rate of peptides [48]. The ACE inhibitory peptides of the walnut glutelin-1 had high stability under low concentrations of salt; as the concentration increased, the ACE inhibitory activity decreased significantly (Figure 7E). This might be because, as the concentration of glucose increases, the Maillard reaction also becomes stronger, and the glycosidic bond of glucose reacts with the amino 
group of the peptide, causing the ACE inhibitory peptide to be consumed, and its inhibitory activity to decrease [49].

The results of this study showed that VERGRRITSV and FVIEPNITPA had good stability under low-concentration salt conditions, but they became less stable under highconcentration salt conditions (Figure 7F). This is because the structure of walnut glutelin-1 ACE inhibitory peptide may change under high salt conditions, and the side chains of amino acids may be damaged by $\mathrm{NaCl}$ treatment, which reduces the ACE inhibitory activity [50].

The ACE inhibitory peptides (VERGRRITSV and FVIEPNITPA) isolated from the hydrolysate of walnut glutelin-1 showed stability across a range of $\mathrm{pH}$ values, at temperatures $<60^{\circ} \mathrm{C}$, and in the presence of metal ions $\left(\mathrm{K}^{+}, \mathrm{Ca}^{2+}\right.$, and $\left.\mathrm{Mg}^{2+}\right)$ under low concentration of salt and glucose. These results indicated that the activity of ACE inhibitory peptides (VERGRRITSV and FVIEPNITPA) would not be greatly affected by appropriate processing conditions, which suggested the possible therapeutic use of these peptides as antihypertensive agents in vivo.

\section{Conclusions}

In this study, two novel peptides (VERGRRITSV and FVIEPDITPA) were successfully isolated and identified from walnut glutelin- 1 hydrolysate. The results of animal experiments showed that the oral administration of the two ACE inhibitory peptides could significantly decrease systolic and diastolic blood pressure in SHRs. On the one hand, the two ACE inhibitory peptides could reduce the AGT, ACE, Ang II, and ALD levels in SHRs by regulating the RAS system. On the other hand, the level of ET-1 decreased, whereas the level of NO in serum increased by regulating the kinin system, lowering the BP level as a consequence. These results suggested that the two ACE inhibitory peptides have the potential to treat hypertension. Moreover, the molecular docking study revealed that the ACE inhibition of VERGRRITSV and FVIEPNITPA were mainly attributed to forming very strong hydrogen bonds with the active pockets of ACE. In addition, the two ACE inhibitory peptides displayed good resistance to digestive enzymes, and they could maintain structural stability in ordinary food processing environments. We have extensively verified that the walnut meal glutelin-1 ACE inhibitory peptides (VERGRRITSV and FVIEPNITPA) exhibited significant ACE inhibitory activity in vitro and in vivo, and concluded that this is a valuable feature to develop antihypertensive drugs and food. Meanwhile, walnut meal may have a potential active ingredient with antihypertensive properties, and its development and utilization as an antihypertensive agent will improve the value of this underutilized protein resource. However, the clinical application of ACE inhibitory peptides is still very limited, and further studies on the clinical efficacy and bioavailability of these peptides in humans needs to be further investigated.

Author Contributions: Conceptualization, J.W. and Y.Z. (Youlin Zhang); methodology, Y.Z. (Yufeng Zhang); formal analysis, G.W.; supervision, Y.Z. (Youlin Zhang); writing—original draft, J.W.; writing - review and editing, J.W., G.W. and R.Z. All authors have read and agreed to the published version of the manuscript.

Funding: This research was funded by Science and Technology Department of Science and Technology Support Project of Shannxi Province (grant number: 2019NY-133,2021NY-132); Key Laboratory of Se-enriched Products Development and Quality Control, Ministry of Agriculture and Rural Affairs/National-Local Joint Engineering Laboratory of Se-enriched Food Development (grant number: Se-2019B03). Research fund projects of Shannxi xueqian normal university (grant number: 2021YBKJ59).

Institutional Review Board Statement: The study was conducted according to the State Community of Science and Technology of China, and the used protocol was approved by the Committee on Care and Use of Laboratory Animals of the Fourth Military Medical University (license number: YXK-007-2007).

Informed Consent Statement: Not applicable. 
Data Availability Statement: All data presented in this study are available on request from the corresponding author. The data are not uploaded in publicly accessible databases.

Acknowledgments: The authors thank Zhong Zhang in Shaanxi Normal University, Zichen Jiang, Jiayao Wang, Jin Fu, Jing Hu and $\mathrm{Na}$ Chen in Shaanxi Xueqian Normal University.

Conflicts of Interest: The authors declare no conflict of interest.

\section{References}

1. Sze-Tao, K.W.C.; Sathe, S.K. Walnuts (Juglans regia L): Proximate composition, protein solubility, protein amino acid composition and protein in vitro digestibility. J. Sci. Food Agric. 2000, 80, 1393-1401. [CrossRef]

2. $\quad$ Li, Y.; Chen, D.; Zhang, F.; Lin, Y.; Ma, Y.; Zhao, S.; Chen, C.; Wang, X.; Liu, J. Preventive effect of pressed degreased walnut meal extracts on T2DM rats by regulating glucolipid metabolism and modulating gut bacteria flora. J. Funct. Foods 2020, 64, 103694. [CrossRef]

3. Majumder, K.; Wu, J. Molecular Targets of Antihypertensive Peptides: Understanding the Mechanisms of Action Based on the Pathophysiology of Hypertension. Int. J. Mol. Sci. 2014, 16, 256-283. [CrossRef]

4. Mirzaei, M.; Mirdamadi, S.; Safavi, M. Structural analysis of ACE-inhibitory peptide (VL-9) derived from Kluyveromyces marxianus protein hydrolysate. J. Mol. Struct. 2020, 1213, 128199. [CrossRef]

5. Khueychai, S.; Jangpromma, N.; Choowongkomon, K.; Joompang, A.; Daduang, S.; Vesaratchavest, M.; Payoungkiattikun, W.; Tachibana, S.; Klaynongsruang, S. A novel ACE inhibitory peptide derived from alkaline hydrolysis of ostrich (Struthio camelus) egg white ovalbumin. Process Biochem. 2018, 73, 235-245. [CrossRef]

6. Natesh, R.; Schwager, S.; Sturrock, E.; Acharya, K.R. Crystal structure of the human ace-lisinopril complex. Nature 2003, 421, 551-554. [CrossRef]

7. McDowell, S.; Coleman, J.; Ferner, R. Systematic review and meta-analysis of ethnic differences in risks of adverse drug reactions to drugs used in cardiovascular MEDICINE. BMJ 2006, 332, 1177-1181. [CrossRef] [PubMed]

8. Asoodeh, A.; Homayouni-Tabrizi, M.; Shabestarian, H.; Emtenani, S.; Emtenani, S. Biochemical characterization of a novel antioxidant and angiotensin I-converting enzyme inhibitory peptide from Struthio camelus egg white protein hydrolysis. J. Food Drug Anal. 2016, 24, 332-342. [CrossRef] [PubMed]

9. Saleh, A.; Zhang, Q.; Shen, Q. Recent Research in Antihypertensive Activity of Food Protein-derived Hydrolyzates and Peptides. Crit. Rev. Food Sci. Nutr. 2014, 56, 760-787. [CrossRef] [PubMed]

10. Sonklin, C.; Alashi, M.A.; Laohakunjit, N.; Kerdchoechuen, O.; Aluko, R.E. Identification of antihypertensive peptides from mung bean protein hydrolysate and their effects in spontaneously hypertensive rats. J. Funct. Foods 2020, 64, 103635. [CrossRef]

11. Guo, M.; Chen, X.; Wu, Y.; Zhang, L.; Huang, W.; Yuan, Y.; Fang, M.; Xie, J.; Wei, D. Angiotensin I-converting enzyme inhibitory peptides from Sipuncula (Phascolosoma esculenta): Purification, identification, molecular docking and antihypertensive effects on spontaneously hypertensive rats. Process Biochem. 2017, 63, 84-95. [CrossRef]

12. Zhang, P.; Chang, C.; Liu, H.; Li, B.; Yan, Q.; Jiang, Z. Identification of novel angiotensin I-converting enzyme (ACE) inhibitory peptides from wheat gluten hydrolysate by the protease of Pseudomonas aeruginosa. J. Funct. Foods 2020, 65, 103751. [CrossRef]

13. Jia, J.; Wu, Q.; Yan, H.; Gui, Z. Purification and molecular docking study of a novel angiotensin-I converting enzyme (ACE) inhibitory peptide from alcalase hydrolysate of ultrasonic-pretreated silkworm pupa (Bombyx mori) protein. Process Biochem. 2015, 50, 876-883. [CrossRef]

14. Tu, M.; Wang, C.; Chen, C.; Zhang, R.; Liu, H.; Lu, W.; Jiang, L.; Du, M. Identification of a novel ACE-inhibitory peptide from casein and evaluation of the inhibitory mechanisms. Food Chem. 2018, 256, 98-104. [CrossRef]

15. Lee, S.Y.; Hur, S.J. Antihypertensive peptides from animal products, marine organisms, and plants. Food Chem. 2017, 228 , 506-517. [CrossRef] [PubMed]

16. Abdel-hamid, M.; Otte, J.; De Gobba, C.; Osman, A. Angiotensin I-converting enzyme inhibitory activity and antioxidant capacity of bioactive peptides derived from enzymatic hydrolysis of buffalo milk proteins. Int. Dairy J. 2017, 66, 91-98. [CrossRef]

17. Qin, X.; Liu, J.; Zhang, Z.; Li, J.; Yuan, L.; Zhang, Z.; Chen, L. Microfluidic paper-based chips in rapid detection: Current status, challenges, and perspectives. TrAC -Trends Anal. Chem. 2021, 143, 116371. [CrossRef]

18. Wang, F.J.; Yin, X.Y.; Regenstein, J.M.; Wang, J.Z. Separation and purification of angiotensin-I-converting enzyme (ACE) inhibitory peptides from walnuts (Juglans regia L.) meal. Eur. Food Res. Technol. 2016, 242, 911-918. [CrossRef]

19. Wang, C.; Song, W.; Jiang, L.; Du, M. Purification and identification of an ACE-inhibitory peptide from walnut protein hydrolysate. Eur. Food Res. Technol. 2014, 239, 333-338. [CrossRef]

20. Wang, J.; Wang, G.; Chen, N.; An, F.; Zhang, R.; Zhang, Y.; Rahman, M.U.; Zhang, Y. Characterization of structural, functional and antioxidant properties and amino acid composition of pepsin-derived glutelin-1 hydrolysate from walnut processing by-products. RSC Adv. 2021, 11, 19158-19168. [CrossRef]

21. Zheng, Y.; Li, Y.; Zhang, Y.; Ruan, X.; Zhang, R. Purification, characterization, synthesis, in vitro ACE inhibition and in vivo antihypertensive activity of bioactive peptides derived from oil palm kernel glutelin-2 hydrolysates. J. Funct. Foods 2017, 28, 48-58. [CrossRef]

22. Li, Y.; Sadiq, F.A.; Fu, L.; Zhu, H.; Zhong, M.; Sohail, M. Identification of angiotensin I-converting enzyme inhibitory peptides derived from enzymatic hydrolysates of razor clam Sinonovacula constricta. Mar. Drugs 2016, 14, 110. [CrossRef] 
23. Abdelhedi, O.; Nasri, R.; Mora, L.; Jridi, M.; Toldrá, F.; Nasri, M. In silico analysis and molecular docking study of angiotensin I-converting enzyme inhibitory peptides from smooth-hound viscera protein hydrolysates fractionated by ultrafiltration. Food Chem. 2018, 239, 453-463. [CrossRef]

24. Hernández-Ledesma, B.; Contreras, M.d.M.; Recio, I. Antihypertensive peptides: Production, bioavailability and incorporation into foods. Adv. Colloid Interface Sci. 2010, 165, 23-35. [CrossRef]

25. García-Moreno, P.; Espejo-Carpio, F.J.; Guadix, A.; Guadix, E. Production and identification of angiotensin I-converting enzyme (ACE) inhibitory peptides from Mediterranean fish discards. J. Funct. Foods 2015, 18, 95-105. [CrossRef]

26. Pan, S.; Wang, S.; Jing, L.; Yao, D. Purification and characterisation of a novel angiotensin-I converting enzyme (ACE)-inhibitory peptide derived from the enzymatic hydrolysate of Enteromorpha clathrata protein. Food Chem. 2016, 211, 423-430. [CrossRef]

27. Liu, C.; Fang, L.; Min, W.; Liu, J.; Li, H. Exploration of the molecular interactions between angiotensin-I-converting enzyme (ACE) and the inhibitory peptides derived from hazelnut (Corylus heterophylla Fisch.). Food Chem. 2018, 245, 471-480. [CrossRef] [PubMed]

28. Ngo, D.H.; Vo, T.S.; Ryu, B.M.; Kim, S.K. Angiotensin-I-converting enzyme (ACE) inhibitory peptides from Pacific cod skin gelatin using ultrafiltration membranes. Process Biochem. 2016, 51, 1622-1628. [CrossRef]

29. Fu, Y.; Alashi, A.; Young, J.; Therkildsen, M.; Aluko, R. Enzyme inhibition kinetics and molecular interactions of patatin peptides with angiotensin I-converting enzyme and renin. Int. J. Biol. Macromol. 2017, 101, 207-213. [CrossRef] [PubMed]

30. Chougule, R.; Kamanna, S. A variant peptide of buffalo colostrum $\beta$-lactoglobulin inhibits angiotensin I-converting enzyme activity. Eur. J. Med. Chem. 2012, 53, 211-219. [CrossRef]

31. Abdelhedi, O.; Nasri, R.; Jridi, M.; Mora, L.; Oseguera-Toledo, M.E.; Aristoy, M.C.; Ben Amara, I.; Toldrá, F.; Nasri, M. In silico analysis and antihypertensive effect of ACE-inhibitory peptides from smooth-hound viscera protein hydrolysate: Enzyme-peptide interaction study using molecular docking simulation. Process Biochem. 2017, 58, 145-159. [CrossRef]

32. Lee, J.K.; Jeon, J.K.; Byun, H.G. Antihypertensive effect of novel angiotensin I converting enzyme inhibitory peptide from chum salmon (Oncorhynchus keta) skin in spontaneously hypertensive rats. J. Funct. Foods 2014, 7, 381-389. [CrossRef]

33. Park, S.Y.; Je, J.Y.; Kang, N.; Han, E.J.; Um, J.H.; Jeon, Y.J.; Ahn, G.; Ahn, C.B. Antihypertensive effects of Ile-Pro-Ile-Lys from krill (Euphausia superba) protein hydrolysates: Purification, identification and in vivo evaluation in spontaneously hypertensive rats. Eur. Food Res. Technol. 2017, 243, 719-725. [CrossRef]

34. Aluko, R. Food protein-derived renin-inhibitory peptides: In vitro and in vivo properties. J. Food Biochem. 2018, 43 , e12648. [CrossRef]

35. Schiffrin, E. Vascular endothelin in hypertension. Vascul. Pharmacol. 2005, 43, 19-29. [CrossRef] [PubMed]

36. Chung, B.-H.; Kim, S.; Kim, J.-D.; Lee, J.; Baek, Y.-Y.; Jeoung, D.; Lee, H.; Choe, J.; Ha, K.-S.; Won, M.-H.; et al. Syringaresinol causes vasorelaxation by elevating nitric oxide production through the phosphorylation and dimerization of endothelial nitric oxide synthase. Exp. Mol. Med. 2011, 44, 191-201. [CrossRef]

37. Xu, B.-C.; Long, H.-B.; Luo, K.-Q. Tert-butylhydroquinone lowers blood pressure in AngII-induced hypertension in mice via proteasome-PTEN-Akt-eNOS pathway. Sci. Rep. 2016, 6, 29589. [CrossRef] [PubMed]

38. Akillioğlu, H.G.; Karakaya, S. Effects of heat treatment and in vitro digestion on the angiotensin converting enzyme inhibitory activity of some legume species. Eur. Food Res. Technol. 2009, 229, 915-921. [CrossRef]

39. Wu, J.; Ding, X. Characterization of inhibition and stability of soy-protein-derived angiotensin I-converting enzyme inhibitory peptides. Food Res. Int. 2002, 35, 367-375. [CrossRef]

40. Bhaskar, B.; Ananthanarayan, L.; Jamdar, S. Purification, identification, and characterization of novel angiotensin I-converting enzyme (ACE) inhibitory peptides from alcalase digested horse gram flour. LWT 2019, 103, 155-161. [CrossRef]

41. Xue, L.; Wang, X.; Hu, Z.; Wu, Z.; Wang, L.; Wang, H.; Yang, M. Peptides Identi fi cation and characterization of an angiotensinconverting enzyme inhibitory peptide derived from bovine casein. Peptides 2018, 99, 161-168. [CrossRef]

42. Toopcham, T.; Roytrakul, S.; Yongsawatdigul, J. Characterization and identification of angiotensin I-converting enzyme (ACE) inhibitory peptides derived from tilapia using Virgibacillus halodenitrificans SK1-3-7 proteinases. J. Funct. Foods 2015, 14, 435-444. [CrossRef]

43. Li, M.; Xia, S.; Zhang, Y.; Li, X. LWT-Food Science and Technology Optimization of ACE inhibitory peptides from black soybean by microwave- assisted enzymatic method and study on its stability. LWT -Food Sci. Technol. 2018, 98, 358-365. [CrossRef]

44. Chen, C.; Chi, Y.J.; Zhao, M.Y.; Xu, W. Influence of degree of hydrolysis on functional properties, antioxidant and ACE inhibitory activities of egg white protein hydrolysate. Food Sci. Biotechnol. 2012, 21, 27-34. [CrossRef]

45. Nasri, R.; Younes, I.; Jridi, M.; Trigui, M.; Bougatef, A.; Nedjar-Arroume, N.; Dhulster, P.; Karra Chaabouni, M. ACE inhibitory and antioxidative activities of Goby (Zosterissessor ophiocephalus) fish protein hydrolysates: Effect on meat lipid oxidation. Food Res. Int. 2013, 54, 552-561. [CrossRef]

46. Li, Y.; Zhang, L.; Zhang, L.; Zhang, H.; Zhang, N.; Yang, Z.; Gao, M.; Yang, X.; Cui, L. High-dose glucose-insulinpotassium has hemodynamic benefits and can improve cardiac remodeling in acute myocardial infarction treated with primary Percutaneous coronary intervention: From a randomized controlled study. J. Cardiovasc. Dis. Res. 2010, 1, 104-109. [CrossRef]

47. Lai, X.; Pan, S.; Zhang, W.; Sun, L.; Li, Q.; Chen, R.; Sun, S. Properties of ACE inhibitory peptide prepared from protein in green tea residue and evaluation of its anti-hypertensive activity. Process Biochem. 2020, 92, 277-287. [CrossRef]

48. Hwang, I.G.; Kim, H.Y.; Woo, K.S.; Lee, J.; Jeong, H.S. Biological activities of Maillard reaction products (MRPs) in a sugar-amino acid model system. Food Chem. 2011, 126, 221-227. [CrossRef] 
49. Wang, H.; Li, Y.; Cheng, Y.; Yin, L.; Li, L. Effect of the Maillard Reaction on Angiotensin I-Converting Enzyme (ACE)-Inhibitory Activity of Douchi During Fermentation. Food Bioprocess Technol. 2013, 6, 297-301. [CrossRef]

50. Mirzaei, M.; Mirdamadi, S.; Safavi, M.; Hadizadeh, M. In vitro and in silico studies of novel synthetic ACE-inhibitory peptides derived from Saccharomyces cerevisiae protein hydrolysate. Bioorg. Chem. 2019, 87, 647-654. [CrossRef] 